INTERNATIONAL JOURNAL OF MULTidisciplinARY RESEARCH AND ANALYSis

ISSN(print): 2643-9840, ISSN(online): 2643-9875

Volume 05 Issue 02 February 2022

DOI: 10.47191/ijmra/v5-i2-19, Impact Factor: 6.072

Page No. $366-371$

\title{
Is The Satisfaction Moderate the Influence of Brand Image and Brand Trust Toward Loyalty of Student?
}

\author{
Totok Haryanto ${ }^{1}$, Imam Faisal Hamzah ${ }^{2}$, Herdian ${ }^{3}$ \\ $1,2,3$ University of Muhammadiyah Purwokerto, Indonesia
}

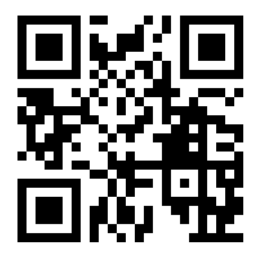

ABSTRACT: This study aims to analyze and determine the effect of brand image and college brand trust towards student loyalty and student satisfaction as intervening variables. The number of respondents in this study is 360 students who will be taken as a sample. Then the analytical test used is the Smart PLS 3.0 software. The results of this study shows that the brand image and brand trust have the significance effect on loyalty. However, the brand image has no influence on the student satisfaction, and the following result also shows that the loyalty has not affected by satisfaction of student. Brand image and brand trust has no effect on loyalty through the satisfaction of student.

KEYWORDS- brand image, brand trust, loyalty, satisfaction

\section{INTRODUCTION}

The existence of universities, in addition to quality and quantity in meeting adequate facilities for the entire academic community, also needs to pay attention to branding strategies. Students who become "customers" of higher education still have to get attention from all elements. However, students who are satisfied with the services and facilities they receive will have a positive impact on the university. In the process of acquiring new students during the enrollment period and retaining students who are already studying, universities must develop a competitive advantage that focuses on the quality of their services (Helgesen \& Nesset, 2007).

Competition between universities is growing along with the digital era that has entered every aspect of education. According to Ramadhan (2020), that every university, both public and private, strives to improve its excellence. These advantages are expected to provide different values from other universities (Haryono \& Octavia 2020). Meanwhile, according to Mujahidin, et al., (2018), alumni recommendations can also increase the number of students. The patterns and strategies of each of these universities, of course, are to maintain the reputation of the university in the aspect of the assessment of the accreditation agency, or more importantly, the community's assessment. It is this public perception that must be built, including the perception of students who have become part of the university. Their existence will determine the survival of the university. Thus, student satisfaction must be a priority, so that they continue to study at the university until graduation.

According to Ambartiasari, et al. (2018), student loyalty will be strongly influenced by student satisfaction who expects what students want. Students' expectations for these universities must be considered and accommodated. Students as the main stakeholders of higher education should be able to get what they want (Amin, 2017). Student loyalty creates a brand image for colleges during and after their campus life, therefore student loyalty refers to loyalty both during and after the student's study period in college (Hennig-Thurau, et al., 2001).

The challenges of higher education in an effort to maintain a brand image in order to maintain a positive perception in society are increasingly complex. So that universities must remain consistent and continue to improve in providing the best service to students. Students can also be said to be "brand ambassadors" of universities, meaning that whatever their opinions are, they will shape perceptions in society. Having students who want to recommend the college they choose is not an easy problem (Hafifi, 2018). Thus, higher education management must continue to improve to maintain the level of student satisfaction during studies. If student satisfaction is getting better, student loyalty will also be maintained. Because student loyalty is very important for the sustainability and management of higher education (Lewa, 2020). It is possible that the student will provide recommendations to others to enter college. Based on the research results of Nafil \& Nasib (2019), it is stated that many universities have involved students in marketing efforts to increase public interest in higher education. In other words, that the existence of student loyalty will also have an impact on the promotion costs of a university which can be minimized (Fadli, et al., 2020). 


\section{Is The Satisfaction Moderate the Influence of Brand Image and Brand Trust Toward Loyalty of Student?}

According to Nikmah (2015), student satisfaction is one indicator of the success of a university in carrying out its duties and functions as an educational institution. With positive student satisfaction, of course it will affect their behavior in recommending to the public. Universities must continue to conduct surveys on the satisfaction of the performance of lecturers and education staff in providing the expected value to students. So that the survey results can be used as input in improving better services to students (Lestari, et al., 2019). Thus, this will be a proof of the university's commitment in providing satisfaction to all parties.

The brand image of a university is a reflection of how the higher education institution is perceived by the community and stakeholders. Accurate information about the quality of a university is very much needed by the community in order to find a college as a destination for study. Thus, higher education management must also pay attention to what information will be used in marketing programs to create a good brand image in the public. According to Pramudyo (2016), the results of his research state that brand image will be very supportive, especially for prospective new students to decide which university has the best quality. This decision is certainly not easy, considering that prospective students will compare all the brand images of other universities (Lestari, et al., 2019).

The next factor that is no less important in influencing student satisfaction, and then student loyalty, cannot be separated from the important role of the university's brand trust. Students' trust in universities has a huge impact on the reputation and credibility of the college. Although, internally, the reputation of the university is also strongly supported by the quality of the implementation of the tri dharma or even the chess dharma of the university which is carried out by all lecturers. However, according to Syaifullah (2018), students' trust in higher education should not be misinterpreted because it will have a major impact on the future of the university. This of course is closely related to the brand trust built and maintained by universities.

The quality of higher education is closely related to the value at the college. Quality universities can be seen from various aspects, including aspects of accreditation, completeness of lecture facilities, collaboration with domestic and foreign institutions, as well as various internationalization programs and scholarship offers. The process of creating shared value in the type of mental stimulus from services such as higher education is very important, because its success can only be achieved through the involvement and relationship of students with universities to participate in creating the best services.

According to Robinson \& Celuch (2016), a university must remain aware that students are supporters who create genuine value in the delivery of educational services. Higher education value creation efforts are also inseparable from the active participatory role of students to interact and collaborate with teachers or lecturers (Dollinger, et al., 2018). Strong brand relationships are needed by higher education institutions to increase awareness of their existence or often referred to as brand awareness (Fleischman, et al., 2015).

In terms of brand awareness of a university, it is closely related to how the university's efforts are in developing brand relationships with students in particular and society in general. Universities that have good quality with all aspects attached to the institution, will not be conveyed properly and widely to the public, if there is no good brand management. Brand management or often called branding, not only conveys about the quality of the university, but is also closely related to efforts to maintain quality and also focuses on student satisfaction as stakeholders.

Based on the description that has been stated in the objectives and objective research, the hypothesis proposed are:

Hypothesis 1: Brand image has a positive effect on satisfaction of student at the private university.

Hypothesis 2: Brand trust has a positive effect on satisfaction of student at the private university.

Hypothesis 3: Brand image has a positive effect on loyalty of student at the private university.

Hypothesis 4: Brand trust has a positive effect on loyalty of student at the private university.

Hypothesis 5: Satisfaction of student has a positive effect on loyalty of student at the private university.

Hypothesis 6: Satisfaction of student mediate the effect of brand image on loyalty of student at the private university.

\section{METHODOLOGY}

This research will be conducted using quantitative research methods based on the primary data that collected from the student through online questionnaire. Then, for the next stage is tabulate data using a Likert scale, with a score of 1 to 5 .

There are 3 (three) types of variables, namely:

a) The dependent variable: student loyalty $(\mathrm{Y})$.

b) Independent variables, involve of brand image (X1), and brand trust (X2).

c) Mediating variables: student satisfaction (M).

This study uses data analysis, namely Partial Least Square (PLS) analysis. 


\section{Is The Satisfaction Moderate the Influence of Brand Image and Brand Trust Toward Loyalty of Student?}

\section{RESULT AND DISCUSSION}

The approach used in this research is the quantitative approach. This study uses a questionnaire given to respondents, namely students in private university. Respondents who fill the online questionnare in this study were 360 students. This study uses data analysis, namely Partial Least Square (PLS) analysis. The research instrument test included an inner model test, outer model, path diagram conversion, estimation, goodness of fit and hypothesis tester (Resampling Bootstrapping).

A. Convergence Test Validity

The result of convergence test validity of indicators that have values less than 0,500 must be excluded from the model because they are considered to be unreliable and insignificant. Furthermore, a reestimation of the model is performed. The result obtained from this study are all indicators of variables that have a value of more than 0.500 can be used to be used as a measurement tool.

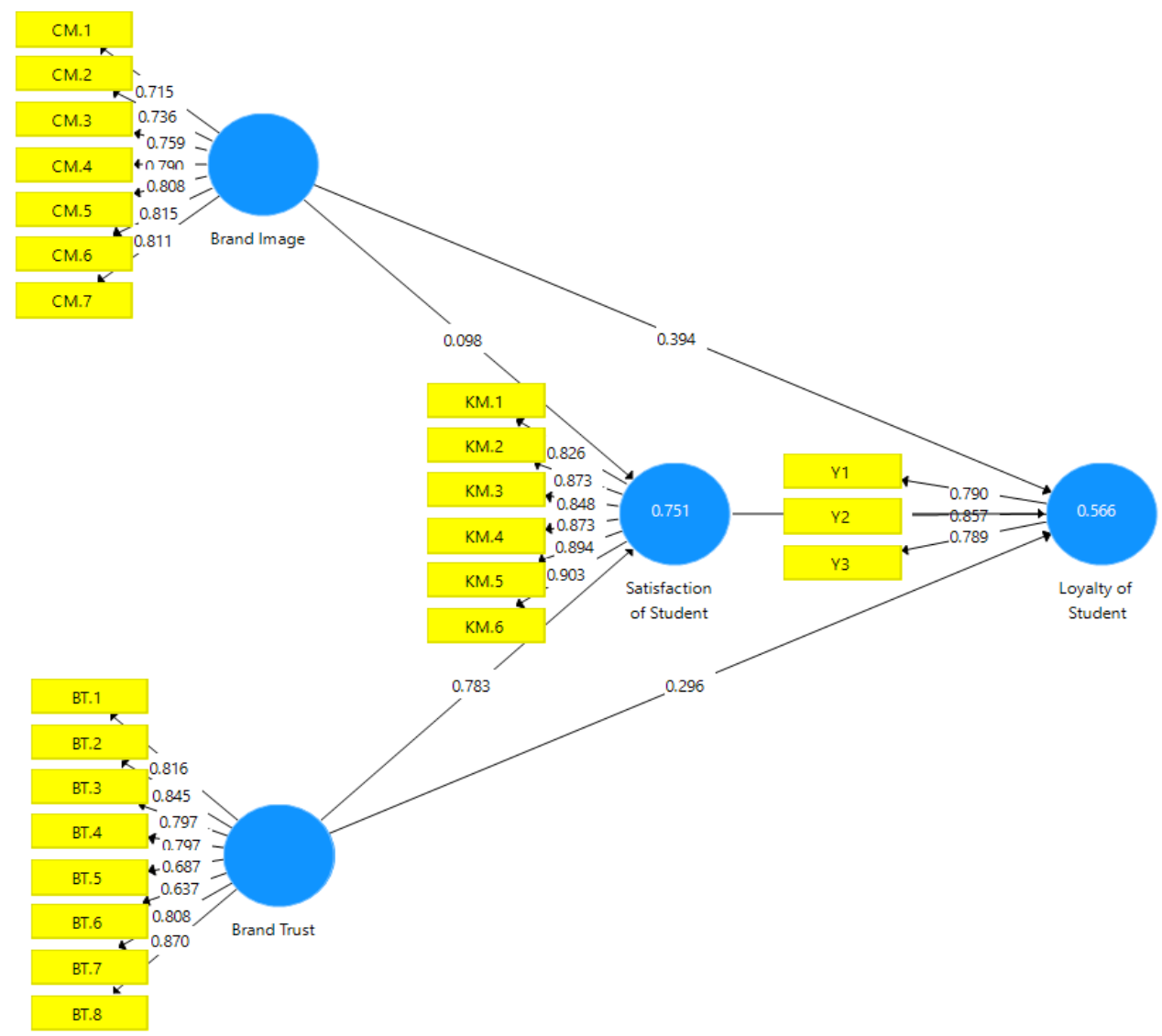

Figure 1. Research Framework (PLS Model)

\section{B. Discriminant Validity Test}

Discriminant validity refers to the degree of discrepancy between attributes that should not be measured by the measuring instrument and theoretical concepts about the variable. Discriminant validity can be said to be achieved if the Average Variance Extracted (AVE) valueis graters than 0.500.

Table 1. Discriminant Validity Test

\begin{tabular}{|l|l|}
\hline Variables & Average Variance Extracted (AVE) \\
\hline Brand Trust & 0.617 \\
\hline Brand Image & 0.604 \\
\hline Satisfaction of Student & 0.757 \\
\hline Loyalty of Student & 0.661 \\
\hline
\end{tabular}

\section{Composite Reliability Test}

A composite reliability test is performed to test the reliability of the research variables. Table 2 is illustrated the composite reliability test results. 
Is The Satisfaction Moderate the Influence of Brand Image and Brand Trust Toward Loyalty of Student?

Table 2. Composite Reliability Test

\begin{tabular}{|l|l|}
\hline Variable & Composite Reliability \\
\hline Brand Trust & 0.928 \\
\hline Brand Image & 0.914 \\
\hline Satisfaction of Student & 0.949 \\
\hline Loyalty of Student & 0.854 \\
\hline
\end{tabular}

The reliability composite test is described to be reliable if the composite reliability value is graters than 0.700 . According to the data in table 2 is showed that all of the composite reliability values of variables are reliable.

\section{Structural Model Analysis}

The structural model analysis is done by evaluating the results of estimated path coefficient parameters and their level of significance (less than 0.005 ). The test results for the significance of the path coefficient of each variable can be seen in table 3 , and indirect effect in table 4.

Based on the result in table 3 is shown that the brand image has no effect to satisfaction of student ( $P$ values more than 0.005). As in previous research, it was stated that brand image has no effect on satisfaction (Wahyuni \& Ghozali, 2019); (Gunardi \& Erdiansyah, 2019); (Rofiq, Firdi, \& Respati, 2020). Likewise, the satisfaction of student has no influence towards the loyalty (Hayati, et.al, 2021); (Aprilia, 2021); (Nurdyastuti \& Awatara, 2018).

Table 3. Parameter Coefficient and Statistical Values among Variables

\begin{tabular}{|l|l|l|l|l|l|}
\hline & $\begin{array}{l}\text { Original } \\
\text { Sample (O) }\end{array}$ & $\begin{array}{l}\text { Sample } \\
\text { Mean (M) }\end{array}$ & $\begin{array}{l}\text { Standard } \\
\text { Deviation (STDEV) }\end{array}$ & $\begin{array}{l}\text { T Statistics } \\
\text { (|O/STDEV|) }\end{array}$ & $\begin{array}{l}\text { Palues } \\
\text { Valuge }\end{array}$ \\
\hline $\begin{array}{l}\text { Brand Image Loyalty of } \\
\text { Student }\end{array}$ & 0.394 & 0.398 & 0.074 & 5.357 & 0.000 \\
\hline $\begin{array}{l}\text { Brand Image -> Satisfaction } \\
\text { of Student }\end{array}$ & 0.098 & 0.096 & 0.053 & 1.846 & 0.066 \\
\hline $\begin{array}{l}\text { Brand Trust -> Loyalty of } \\
\text { Student }\end{array}$ & 0.296 & 0.294 & 0.100 & 2.965 & 0.003 \\
\hline $\begin{array}{l}\text { Brand Trust -> Satisfaction } \\
\text { of Student }\end{array}$ & 0.783 & 0.784 & 0.051 & 15.363 & 0.000 \\
\hline $\begin{array}{l}\text { Satisfaction of Student -> } \\
\text { Loyalty of Student }\end{array}$ & 0.105 & 0.105 & 0.079 & 1.330 & 0.184 \\
\hline
\end{tabular}

Table 4. Specific Indirect Effects

\begin{tabular}{|l|l|l|l|l|l|}
\hline & $\begin{array}{l}\text { Original } \\
\text { Sample (O) }\end{array}$ & $\begin{array}{l}\text { Sample } \\
\text { Mean (M) }\end{array}$ & $\begin{array}{l}\text { Standard } \\
\text { Deviation (STDEV) }\end{array}$ & $\begin{array}{l}\text { T Statistics } \\
\text { (|O/STDEV|) }\end{array}$ & $\begin{array}{l}\text { P } \\
\text { Values }\end{array}$ \\
\hline $\begin{array}{l}\text { Brand Image -> Satisfaction } \\
\text { of Student } \rightarrow>\text { Loyalty of } \\
\text { Student }\end{array}$ & 0.010 & 0.010 & 0.010 & 1.009 & $\mathbf{0 . 3 1 3}$ \\
\hline $\begin{array}{l}\text { Brand Trust -> Satisfaction } \\
\text { of Student -> Loyalty of } \\
\text { Student }\end{array}$ & 0.082 & 0.082 & 0.062 & 1.314 & $\mathbf{0 . 1 8 9}$ \\
\hline
\end{tabular}

Table 4 showed that $P$ values of specific indirect effects more than 0.005 , which means that the brand image has no influence on loyalty of student through satisfaction of student. Including the results of the analysis the effect of brand trust toward loyalty of student, there is no significant effects that mediated by satisfaction of student.

\section{CONCLUSIONS}

The result showed that the brand image and brand trust become the variable that have the significant influence on loyalty of student, respectively. In other side, brand trust also has the significant effect on satisfaction of student. On contrary, brand image 


\section{Is The Satisfaction Moderate the Influence of Brand Image and Brand Trust Toward Loyalty of Student?}

has no effect on student satisfaction, nor does loyalty affect student satisfaction. Brand image and brand trust has no effect on loyalty through the satisfaction of student. This means that there is no indirect effect, respectively.

\section{REFERENCES}

1) Ambartiasari, G., Lubis, A. R., \& Chan, S. (2018). Pengaruh Kualitas Pelayanan, Kepercayaan dan Fasilitas Kampus Terhadap Kepuasan Dan Dampaknya Kepada Loyalitas Mahasiswa Politeknik Indonesia Venezuela. Jurnal Manajemen Inovasi, 1223.

2) Amin, S. (2017). Strategi Peningkatan Kualitas Pelayanan Akademik Pada Sekolah Tinggi. Wahana Akademika, $193-202$.

3) Aprilia, N. E. (2021). Influence of Service Quality on Customer Loyalty Through Perceived Risk, Satisfaction, and Trust in Branchless Banking Customers (Study at PT. Bank Rakyat Indonesia (Persero), Tbk Branch Office of Ponorogo). Bisma: Jurnal Bisnis dan Manajemen, 56 - 64.

4) BPS.Jateng. (2020, Juni 15). Jumlah Perguruan Tinggi1, Mahasiswa2, dan Tenaga Pendidik (Negeri dan Swasta) di Bawah Kementerian Riset, Teknologi dan Pendidikan Tinggi/Kementerian Pendidikan dan Kebudayaan Menurut Kabupaten/Kota di Provinsi Jawa Tengah, 2018 dan 2019. Retrieved from jateng.bps.go.id:

https://jateng.bps.go.id/statictable/2020/06/15/1803/jumlah-perguruan-tinggi1-mahasiswa2-dan-tenaga-pendidiknegeri-dan-swasta-di-bawah-kementerian-riset-teknologi-dan-pendidikan-tinggi-kementerian-pendidikan-dankebudayaan-menurut-kabupaten-kota-di-provi

5) Dollinger, M., Lodge, J., \& Coates, H. (2018). Co-creation in higher education: towards a conceptual model. Journal of Marketing for Higher Education, 1-22.

6) Fleischman, D., Raciti, M., \& Lawley, M. (2015). Degrees of co-creation: an exploratory study of perceptions of international students' role in community engagement experiences. Journal of Marketing for Higher Education, 85-103.

7) Gunardi, C. G., \& Erdiansyah, R. (2019). Pengaruh Citra Merek dan Kualitas Pelayanan terhadap Kepuasan Pelanggan Restoran Mangkok Ku. Prologia , 456-463.

8) Harvey, S. (2018, Agustus 29). University branding: Your clever guide to higher education branding. Retrieved from fabrikbrands.com: $\quad$ https://fabrikbrands.com/university-branding-and-higher-education-branding/\#: :text=As\%20 mentioned\%2 0above\%2C\%20a\%20university,of\%20that\%20expense\%20will\%20be.

9) Haryono, N., \& Octavia, R. (2020). Analisis pengaruh citra merek dan mutu layanan terhadap kepuasan konsumen serta dampaknya terhadap loyalitas konsumen. Jurnal Industri Elektro dan Penerbangan, 20-27.

10) Hayati, F., Kamener, D., \& Rosha, Z. (2021). Pengaruh Kualitas Pelayanan Dan Persepsi Nilai Terhadap Loyalitas Dengan Kepuasan Sebagai Variabel Intervening Pada Nasabah Bank BRI Cabang Khatib Sulaiman Padang. ejurnal.bunghatta.ac.id.

11) Helgesen, O., \& Nesset, E. (2007). What accounts for students' loyalty? Some field study evidence. International Journal of Educational Management, 21(2), 126-143.

12) Hennig-Thurau, T., Langer, M., \& Hansen, U. (2001). Modeling and managing student loyalty an approach based on the concept of relationship quality. Journal of Service Research, 331-344.

13) Klassen, M. L. (2002). Relationship Marketing on the Internet: The case of top-and lower-ranked US Universities and Colleges. Journal of Retailing and Consumer Services, 81-85.

14) M.S.Balaji, Roy, S. K., \& Sadeque, S. (2016). Antecedents and consequences of university brand identification. Journal of Business Research, 3023-3032.

15) Mujahidin, A., Zuhriah, F., \& Khoirianingrum, I. (2018). Pengaruh Citra Perguruan Tinggi dan Kompetensi Dosen terhadap Loyalitas Mahasiswa melalui Kepuasan Mahasiswa Pada Perguruan Tinggi Swasta (Studi pada IKIP PGRI Bojonegoro. AI Tijarah, 49.

16) Nurdyastuti, T., \& Awatara, I. G. (2018). The Role of Service and Relationship Quality toward Customer Satisfaction and Loyalty in Bank Jateng Branch of Surakarta. Journal of Applied Economics in Developing Countries, 52-58.

17) Ramadhan, M. A. (2020). Pengaruh Citra Merek, Kepercayaan, dan Komitmen terhadap Loyalitas Pelanggan Aplikasi Transportasi Online Gojek di Kota Malang. Jurnal Ilmu Manajemen (JIMMU), 153.

18) Robinson, N. M., \& Celuch, K. G. (2016). Strategic and bonding effects of enhancing the student feedback process. Journal of Marketing for Higher Education, 20-40.

19) Rofiq, M., Firdi, A., \& Respati, H. (2020). The Effect of Brand Image and Social Media on Customer Retention through Customer Satisfaction at Kaliwatu Adventure. International Journal of Innovative Science and Research Technology, 24562165.

20) Santos, G., Marques, C. S., Justino, E., \& Mendes, L. (2020). Understanding social responsibility's influence on service quality and student satisfaction in higher education. Journal of Cleaner Production. 


\section{Is The Satisfaction Moderate the Influence of Brand Image and Brand Trust Toward Loyalty of Student?}

21) suarabanyumas.com. (2020, Juni 24). Masa Pandemi, Minat Masuk ke UMP Tak Menurun. Retrieved November 1, 2021, from https://suarabanyumas.com/masa-pandemi-minat-masuk-ke-ump-tak-menurun/

22) Sugiyono. (2016). Metode Penelitian Kuantitatif, Kualitatif dan R\&D. Bandung: PT Alfabet.

23) Teh, G. M., \& Salleh, A. H. (2011). Impact of brand meaning on brand equity of higher educational institutions in Malaysia. World Business, 218-228.

24) Waeraas, A., \& Solbakk, M. N. (2009). Defining the essence of a university: Lessons from higher. Higher Education: The International Journal of Higher Education and Educational Planning, 449-462.

25) Wahyuni, S., \& Ghozali, I. (2019). The Impact of Brand Image and Service Quality on Consumer Loyalty in the Banking Sector. International Journal of Economics and Business Administration (IJEBA), 395-402.

26) www.kompas.com. (2020, April 17). Wabah Corona, Penerimaan Mahasiswa Baru di Sejumlah Kampus Swasta Menurun. Retrieved November 1, 2021, from https://www.kompas.com/edu/read/2020/04/17/070000171/wabah-coronapenerimaan-mahasiswa-baru-di-sejumlah-kampus-swasta-menurun.

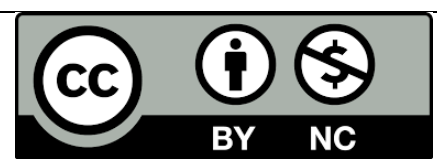

There is an Open Access article, distributed under the term of the Creative Commons Attribution - Non Commercial 4.0 International (CC BY-NC 4.0)

(https://creativecommons.org/licenses/by-nc/4.0/), which permits remixing, adapting and building upon the work for non-commercial use, provided the original work is properly cited. 